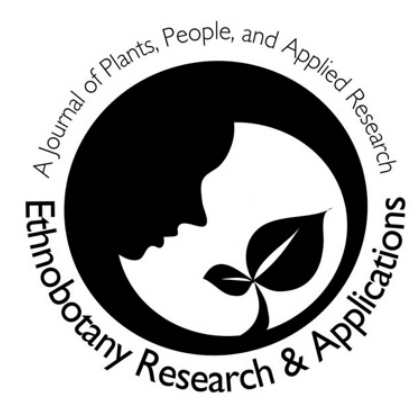

\title{
Ethnobotanical study of medicinal plants for treatment of diabetes and hypertension used in communities near Fathala Forest, Senegal
}

Mariama Diop, Fatimata Niang-Diop, Sara Danièle Dieng, Abdoulaye Samb, Gilberta Elisa Djidiambone Manga, Ansoumana Papa Sané, Mayacine Badara Sène, Bienvenu Sambou, Assane Goudiaby, Eric Arnaud Diatta

\begin{abstract}
Correspondence
Mariama Diop*, Fatimata Niang-Diop, Sara Danièle Dieng, Abdoulaye Samb, Gilberta Elisa Djidiambone Manga, Ansoumana Papa Sané, Mayacine Badara Sène, Bienvenu Sambou, Assane Goudiaby, Eric Arnaud Diatta
\end{abstract}

Institute of Environmental Sciences, Faculty of Science and Technology, Cheikh Anta Diop University of Dakar

*Corresponding Author: mariama24.diop@ucad.edu.sn

Ethnobotany Research and Applications 23:7 (2022)

\section{Research}

\begin{abstract}
Background: Diabetes and hypertension are serious health issues, and both are predicted to increase, particularly in Africa. The objectives of this study are to (1) identify plants used to treat diabetes and hypertension and (2) characterize their therapeutic uses based on ethnobotanical information.
\end{abstract}

Methods. Semi-structured individual and group interviews were conducted with traditional healers, patients, nurses and other actors near Fathala Classified Forest in western Senegal. Data were processed using content analysis. Citation frequency (CF) was used to determine importance of each species.

Results: A total of 38 species were used to treat diabetes and hypertension. These belong to 34 genera and 21 families. Eighteen species were used to treat both diabetes and hypertension, 12 were used to treat hypertension and eight to treat diabetes. The most used plant parts were leaves (56\%) bark (10\%) and roots (10\%). Preparation of the medicine mainly consisted of decoction (45\%), infusion (17\%) and maceration (15\%) and most medicines were taken as a drink (76\%). The most used species in the treatment of diabetes are Terminalia avicennioides ( $\mathrm{FC}=$ $69 \%)$, Sclerocarya birrea ( $\mathrm{FC}=23 \%$ ) and Cocos nucifera $(\mathrm{FC}=15 \%)$. Moringa oleifera ( $\mathrm{FC}=46,15 \%)$, Oxytenanthera abyssinica ( $F C=30,76 \%)$ and Detarium microcarpum ( $F C=23,07 \%)$ are mainly used against hypertension. Combretaceae (28,57\%), Fabaceae (28,57\%) and Anacardiaceae (19,05\%), are most represented families.

Conclusion: A diversity of native plants were used as antidiabetic and antihypertensive medicine. Ethnobotanical knowledge could constitute a foundation for identifying new active ingredients for developing new or improved medicine.

Key words: Africa, antidiabetic, antihypertensive, medicinal plants, traditional knowledge. 


\section{Résumé}

Contexte: Le diabète et l'hypertension sont des problèmes de santé graves avec une augmentation des deux pathologies prévue particulièrement en Afrique. Les objectifs de la présente étude sont (1) d'identifier les plantes utilisées pour traiter le diabète et l'hypertension et (2) de caractériser leurs utilisations thérapeutiques à partir de renseignements ethnobotaniques.

Méthodes: Des entretiens semi-structurés individuels et de groupe ont été menés auprès de guérisseurs traditionnels, de patients, d'infirmières et d'autres acteurs localisés à la périphérie de la forêt classée de Fathala, dans l'ouest du Sénégal. Les données ont été traitées au moyen d'une analyse de contenu. La fréquence des citations (FC) a été utilisée pour déterminer l'importance de chaque espèce.

Résultats: Au total, 38 espèces ont été utilisées pour traiter le diabète et l'hypertension. Elles appartiennent à 34 genres et 21 familles. Dix-huit espèces ont été utilisées pour traiter le diabète et l'hypertension, 12 pour traiter l'hypertension et huit pour traiter le diabète. Les parties les plus utilisées étaient les feuilles (56\%), l'écorce (10\%) et les racines (10\%). Les remèdes étaient principalement préparés sous forme de décoction (45\%), d'infusion (17\%) et de macération (15\%) et la plupart des médicaments étaient administrées par la boisson (76\%). Les espèces les plus utilisées dans le traitement du diabète sont Terminalia avicennioides (FC=69\%), Sclerocarya birrea (FC=23\%) et Cocos nucifera ( $\mathrm{FC}=15 \%)$. Moringa oleifera ( $\mathrm{FC}=46,15 \%)$, Oxytenanthera abyssinica $(\mathrm{FC}=30,76 \%)$, Detarium microcarpum ( $\mathrm{FC}=23,07 \%$ ) sont principalement employés dans les soins contre l'hypertension. Les Combretaceae (28,57\%), les Fabaceae (28,57\%), et les Anacardiaceae (19,05\%) sont les familles les plus représentées.

Conclusion: Une diversité de plantes indigènes a été utilisée comme médicaments antidiabétiques et antihypertenseurs. Les connaissances ethnobotaniques pourraient constituer une base pour l'identification de nouveaux ingrédients actifs pour le développement de médicaments nouveaux ou améliorés.

Mots clés. Afrique, antidiabétique, antihypertenseur, plantes, savoir traditionnel.

\section{Background}

The greatest future increase in the prevalence of diabetes is predicted to occur in Africa (International Diabetes Federation 2017).

Plants are commonly used for treatment of various diseases (Jeddi et al. 2021, Mounkaila et al. 2017). In Africa, about $80 \%$ of the population uses native plants to meet their primary health care needs (Salhi et al. 2010). Protected areas are frequently the source of medicinal plants as they habour a diversity of plants, which are not available in the agricultural lands (Lykke 1994, Doumenge et al. 2001, Mayaux et al. 2007).

The exploitation of medicinal plants raises environmental concerns, as the tonnages collected increase each year (Diop et al. 2019), which is threatening many of the rare species (Ouédraogo et al. 2006).

In Senegal, overexploitation of forest products is one of the main factors that are responsible of the declining number of species (Gueye 2000). The main savanna area of the Saloum Delta National Park, is characterized by a significant decline in its plant resources (Lykke 1994, Niang-Diop et al. 2011). This raises the problem of the conservation of plant species in the face of the risks of pressure and disappearance in an environment subject to strong pressure (Tiébré et al. 2016), particularly in a context of the proliferation of diseases.

Non-communicable diseases such as diabetes and hypertension could pose public health problems and attendant challenges for sustainable development on a global scale (Orch et al. 2015). In Senegal, diabetes, particularly the mellitus type, is increasing (Gning et al. 2007). According to data from the national survey of risk factors for noncommunicable diseases, about 5\% (Ministry of Health and Social Action 2015) of the population suffers from diabetes, with a mortality rate of $3 \%$ (WHO 2016). These alarming figures leave no room for doubt as to the extent of this phenomenon, which have been largely underpinned by socio-economic transformations resulting in hypertension (WHO 2016). Its considerable growth makes it an additional concern, especially for African countries still facing infectious diseases. This is the case in Senegal, where the impact in terms of morbidity, with a rate of $24 \%$ of cases (Ministry of Health and Social Action 2015), makes it urgent to implement control and prevention measures. However, the lack of financial resources in most African countries makes it difficult to provide health care (Assouma et al. 2018). Acting together or separately, diabetes and hypertension require long-term follow-up 
and expensive treatment (Monabeka et al. 1998). The high cost of medical care and adequate management often leads people to turn to traditional medicine (Apema et al. 2011).

Given the prevalence of diabetes and hypertension in Senegal and the role of traditional medicine in the treatment of these two diseases, it would be appropriate to focus on plants and their main uses. Especially, since in Africa, in its western part, poverty has led to reduced performance of public health structures (Gobbers \& Pichard 2000), the only alternative for the populations is the forests (Diop et al. 2011). The aim of this study is to analyze the diversity of medicinal plants and their therapeutic uses for diabetes and hypertension.

\section{Material and Methods}

\section{The study area}

The study was conducted with 30 communities in six villages located in the periphery of Fathala Classified Forest in the Fatick region in western Senegal (Figure 1). Socés and the Sérères Niominka are the predominant ethnic groups. The population is relatively young referring to a social reality linked to the role-taking in the domestic space and to the scale of the global society (Dimé \& Fall 2018). Fathala Classified Forest belongs to the SudanGuinean vegetation zone (Lykke 1994). The average annual rainfall is $592 \mathrm{~mm}$ with a general downward trend. The dry season lasts from June to October and the rainy season from November to May.
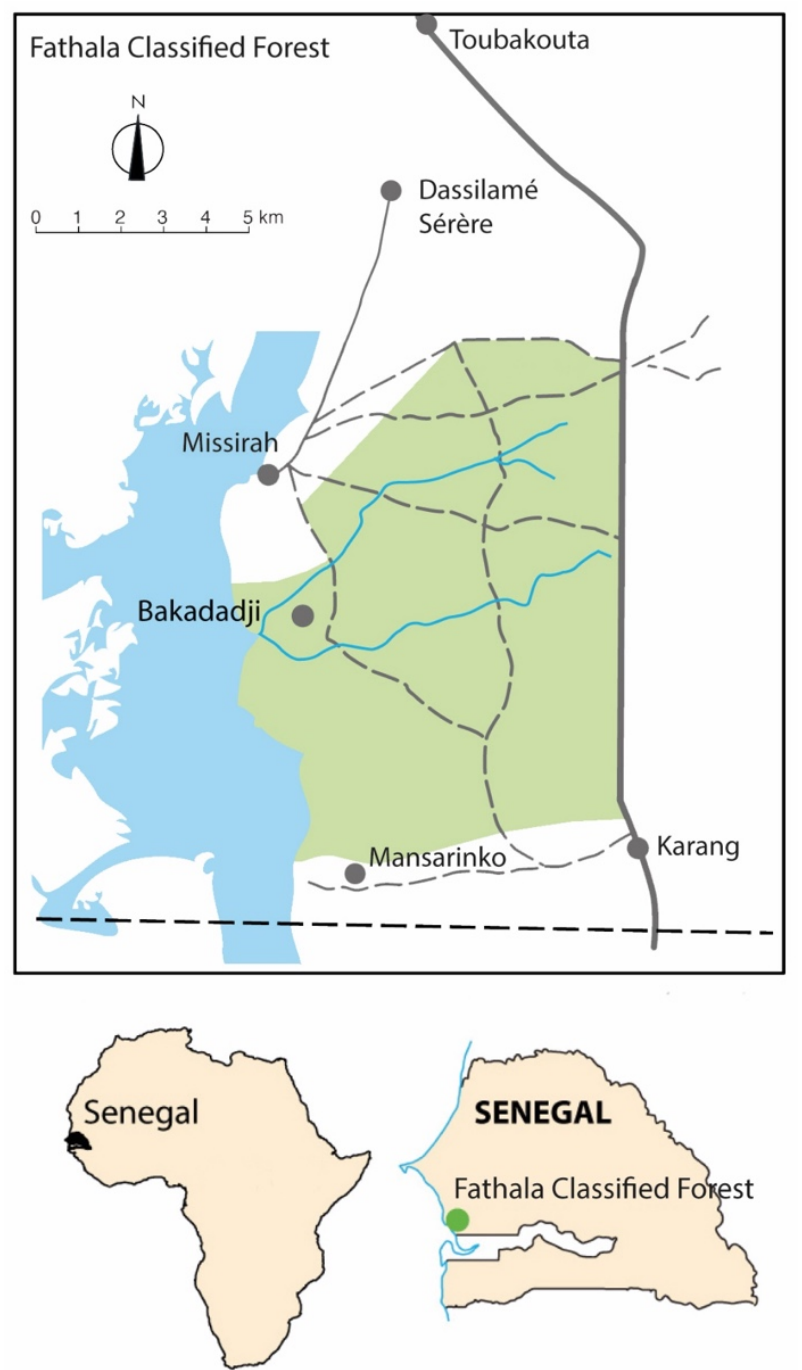

Figure 1. Fathala Classified Forest and surroundings.

\section{Data collection and analysis}

Stakeholders and resource persons were contacted during prospecting visits. Information on the status of diabetes and hypertension and the role of plants for treatment was gathered from informal interviews using the snowball method (Martín-López et al. 2011). Deeper surveys were conducted from March to April 2019 in six villages (Toubakouta, Bakadadji, Missira, Karang, Dassilamé Sérère and Mansarinko) located within a $5 \mathrm{~km}$ radius of the forest (Figure 1). This included group interviews with 10-12 people in two villages (Mansarinko and Bakadadji) and semistructured individual questionnaires with 30 informants in six locations. Informal discussions were held with 6 traditional healers, 3 patients reported to be suffering from hypertension and/or diabetes, 3 Nurse Post Managers, and other actors who do not belong to any particular category. The choice of actors is based on specific criteria: The traditional healers are the essential actors in the field of traditional medicine, they have knowledge and know-how inherited from their ancestors or learned and perfected over time. Patients are the main users and beneficiaries of medicinal plants. Nurses Post Managers are trained in the medical field and interact with the patients. In addition, diabetes and hypertension are diagnosed in health facilities. Other knowledgeable people include local healers, this group has a broad knowledge of therapeutic practices used to relieve ailments and prevent potential pathological risks.

The main questions addressed during the interviews concerned the perception of the two diseases, plants, and their therapeutic uses. The identification of species was done on site with the help of the informants or identified on the basis of floras (Berhaut 1967, Arbonier 2019). Species and family names have been verified on The Plant List. Interviews were supplemented by direct observation by visiting sites with informants. 
The interviews were transcribed. The scientific species name, plant family and reported therapeutic uses were compiled in excel. The importance of each species was determined from the Frequency of Citation (Dossou et al. 2021, Vitalini et al. 2013): $F C=n / N^{*} 100$. Where $n=$ number of respondents who stated the use of a species to treat diabetes and/or hypertension and $\mathrm{N}=$ total number of informants interviewed. For each species family, the relative frequency was calculated: $F=$ Number of species in a family/Total number of families. The basic elements used in the preparation of remedies are composed of parts of the plant. These consist of leaves with roots, fruit and bark. The characterization of the therapeutic preparation involves the identification of the methods by which the parts of the plant used are transformed into local medicinal products. This step is also followed by the identification of the way in which the remedy is applied.

A content analysis was also conducted with qualitative data. It is a systematic and methodical review of textual or visual documents (Diop 2011).

\section{Results}

\section{Species richness}

A total of 38 medicinal species were used to treat diabetes and hypertension. These species belong to 34 genera and 21 families. The most represented families were Combretaceae with six species $(F=28,57 \%)$, Fabaceae $(F=28,57 \%)$, Anacardiaceae with four species $(F=19,05 \%)$, followed by Amaryllidacea, Annonaceae and Poaceae with two species each ( $F=9.52 \%)$. All other families have only one or two species.

Of the 38 species recorded, 12 were used against hypertension, eight against diabetes and 18 against both diabetes and hypertension (Figure 2).

\section{Species used against hypertension}

The main species considered to have anti-hypertensive effects were Neocarya macrophylla (Sabine) Prance (FC=15\%), Balanites aegyptiaca (L.) Delile (15\%) and Cola cordiflolia (Cav.) R.Br. (FC=15\%). Other less cited species were Flueggea virosa (Roxb. ex Willd.) Royle, Saba senegalensis (A.DC.) Pichon, Senna occidentalis (L.) Rose, Abelmoschus esculentus (L.) Moench, Dialium guineense Wild., Terminalia macroptera Guill. \& Perr., Psorospermum senegalense Spach, Mangifera indica L. and Lepisanthes senegalensis (Poir.) Leenh. (FC=8\%) (Figure 2).

\section{Species used against diabetes}

It appears in this study that the most cited species are Terminalia avicennioides Guill. \& Perr. (FC=69\%), Sclerocarya birrea (A. Rich.) Hochst ( $\mathrm{FC}=23 \%$ ) and Cocos nucifera ( $\mathrm{FC=15 \% ).} \mathrm{Bobgunnia} \mathrm{madagascariensis} \mathrm{(Desv.)} \mathrm{JHKirkbr.} \mathrm{\&}$ Wiersema, Ozoroa insignis Delile, Guiera senegalensis J.F. Gmel., Combretum nigricans var. and Hexalobus monopetalus Engl. \& Diels follow with only 7,69\% quotes each.

\section{Species used for both diabetes and hypertension}

Species that are mainly used against these two diseases are Moringa oleifera Lam. (FC=46,15\%), Oxytenanthera abyssinica Munro. ( $F C=30,76 \%)$, Detarium microcarpum G. and Perr, Annona muricata L. and Anacardium occidentale L. (FC=23,07\%). These are followed by Ziziphus jujuba Mill. (FC=23,07\%) Combretum micranthum $\mathrm{G}$. Don. (FC $=15,38 \%)$, Combretum glutinosum Perr. ex DC. (15,38\%), Tamarindus indica L. (FC=15,38\% and Arachis hypogaeae $\mathrm{L}$. ( $\mathrm{FC}=15,38 \%)$. The least commonly cited species are represented byMomordica charantia $\mathrm{L}$. ( $\mathrm{FC}=$ 7,69\%), Zingiber officinale Roscoe. (FC=7,69\%), Allium cepa L. (FC=7,69\%), Allium sativum L. (FC=7,69\%), Cymbopogon citratus (DC) Stapf. ( $F C=7,69 \%)$ Artemisia annua L. ( $F C=, 69 \%)$, Ocimum basilicum L. (FC=7,69\%), Lawsonia inermis L. (FC=7,69\%), 
Table 1 List of species used for treatment of diabetes and hypertension

\begin{tabular}{|c|c|c|c|c|c|c|}
\hline Species & Family & Disease & $\begin{array}{l}\text { Plant parts } \\
\text { used }\end{array}$ & Preparation & Consumption & $\begin{array}{l}\text { Citation } \\
\text { Frequency (\%) }\end{array}$ \\
\hline Allium cepa L. & Amaryllidaceae & Diabetes + Hypertension & Bulb & Cut out & Chew & 7.69 \\
\hline Allium sativum $\mathrm{L}$. & Amaryllidaceae & Diabetes + Hypertension & Bulb & Cut out & Eat & 7.69 \\
\hline \multirow[t]{3}{*}{ Anacardium occidentale L. } & \multirow[t]{6}{*}{ Anacardiaceae } & Diabetes & Fruit & Grill the fruit & Eat & \multirow[t]{3}{*}{23.07} \\
\hline & & \multirow[t]{2}{*}{ Diabetes + Hypertension } & Bark & $\begin{array}{l}\text { Remove the first black } \\
\text { layer, Macerate one } \\
\text { handle in one liter of } \\
\text { water }\end{array}$ & $\begin{array}{l}\text { Drink a liter everynight } \\
\text { until signs disappear }\end{array}$ & \\
\hline & & & Floral peduncle & $\begin{array}{l}\text { Extract juice from the } \\
\text { pulp }\end{array}$ & $\begin{array}{l}\text { Drinking until signs } \\
\text { disappear }\end{array}$ & \\
\hline Mangifera indica $\mathrm{L}$. & & Hypertension & Leaves & Decoction & Drink until signs disappear & 7.69 \\
\hline Ozoroa insignis Delile & & Diabetes & Leaves & Decoction & Drink until signs disappear & 7.69 \\
\hline $\begin{array}{l}\text { Sclerocarya birrea (A. Rich.) } \\
\text { Hochst. }\end{array}$ & & Diabetes & Bark / Leaves & Decoction or Tea & $\begin{array}{l}\text { Drink a cup twice/day for a } \\
\text { week }\end{array}$ & 23.07 \\
\hline Annona muricata L. & \multirow[t]{2}{*}{ Annonaceae } & Diabetes + Hypertension & Leaves & Decoction & $\begin{array}{l}\text { Drink a cup/ day until signs } \\
\text { disappear }\end{array}$ & 23.07 \\
\hline $\begin{array}{l}\text { Hexalobus monopetalus } \\
\text { Engl. \& Diels }\end{array}$ & & Diabetes & Leaves & Decoction & $\begin{array}{l}\text { Drink a cup morning and } \\
\text { night }\end{array}$ & 7.69 \\
\hline $\begin{array}{l}\text { Saba senegalensis (A. DC.) } \\
\text { Pichon. }\end{array}$ & Apocinaceae & Hypertension & Leaves & $\begin{array}{l}\text { Decoction with one } \\
\text { liter of water }\end{array}$ & $\begin{array}{l}\text { Drink } 1 / 2 \text { liter allmorning } \\
\text { and evening }\end{array}$ & 7.69 \\
\hline Cocos nucifera L. & Arecaceae & Diabetes & Bark & Decoction & Drink a cup/day & 15.38 \\
\hline Artemisia annua L. & Compositae & Diabetes + Hypertension & Leaves & Powder & Eat & 7.69 \\
\hline $\begin{array}{l}\text { Neocarya macrophylla } \\
\text { (Sabine ) Prance }\end{array}$ & Chrysobalanaceae & Hypertension & Leaves & Infuse 3 leaves & Drink twice a day & 15.38 \\
\hline $\begin{array}{l}\text { Combretum glutinosum Perr. } \\
\text { ex DC. }\end{array}$ & \multirow[t]{5}{*}{ Combretaceae } & Diabetes + Hypertension & Leaves & Decoction with 7 leaves & Drink until signs disappear & 15.38 \\
\hline $\begin{array}{l}\text { Combretum micranthum } \mathrm{G} \text {. } \\
\text { Don. }\end{array}$ & & Diabetes/ Hypertension & Leaves & Tea/ Decoction & $\begin{array}{l}\text { Drink regularly / Drink } 1 / 2 \\
\text { cup in the morning and } \\
1 / 2 \text { cup in the evening }\end{array}$ & 15.38 \\
\hline $\begin{array}{l}\text { Combretum nigricans var. } \\
\text { elliotii (Angl. \& Diels) } \\
\text { Aubrév. }\end{array}$ & & Diabetes & Leaves & Decoction & $\begin{array}{l}\text { Drink a cup in the morning } \\
\text { and a cup in the evening }\end{array}$ & 7.69 \\
\hline $\begin{array}{l}\text { Terminalia avicennoides } \\
\text { Guill. and Perr }\end{array}$ & & Diabetes & Roots /Bark & $\begin{array}{l}\text { Decoction in tea/ } \\
\text { Maceration }\end{array}$ & $\begin{array}{l}\text { Drink regularly/ Drink one } \\
\text { cup in the morning, one in } \\
\text { the afternoon and one in } \\
\text { the evening }\end{array}$ & 69.23 \\
\hline $\begin{array}{l}\text { Terminalia macroptera Guill. } \\
\text { And Perr }\end{array}$ & & Hypertension & Leaves & Decoction & Drink regularly & 7.69 \\
\hline
\end{tabular}


Ethnobotany Research and Applications

\begin{tabular}{|c|c|c|c|c|c|c|}
\hline Momordica charantia L. & Cucurbitaceae & Diabetes / Hypertension & Leaves & $\begin{array}{l}\text { Decoction to make the } \\
\text { smell disappear }\end{array}$ & Drink one $1 / 2$ cup/day & 7.69 \\
\hline $\begin{array}{l}\text { Bobgunnia madagascariensis } \\
\text { (Desv.) JHKirkbr. \& Wiersema }\end{array}$ & \multirow[t]{6}{*}{ Fabaceae } & Diabetes & Leaves & Decoction & $\begin{array}{l}\text { Drink a cup in the morning } \\
\text { and a cup in the evening }\end{array}$ & 7.69 \\
\hline Arachis hypogaea L. & & Diabetes & Hull & Decoction & Drink regularly & 15.38 \\
\hline $\begin{array}{l}\text { Detarium microcarpum G. } \\
\text { and Perr. }\end{array}$ & & Diabetes/Hypertension & Bark & Maceration & $\begin{array}{l}\text { Pose on head / Drink until } \\
\text { signs disappear }\end{array}$ & 23.07 \\
\hline Dialium guineense Wild & & Hypertension & Leaves & Decoction & Drink until signs disappear & 7.69 \\
\hline Senna occidentalis L. & & Hypertension & Seed & Roasted seed powder & Drink dissolved in water & 7.69 \\
\hline Tamarindus indica $\mathrm{L}$. & & Diabetes + Hypertension & Fruit & $\begin{array}{l}\text { Extract the pulp from } \\
\text { the pod }\end{array}$ & Suck & 15.38 \\
\hline $\begin{array}{l}\text { Psorospermum senegalense } \\
\text { Spach. }\end{array}$ & Hypericaceae & Hypertension & Roots & Maceration & Drink until signs disappear & 7.69 \\
\hline Ocimum basilicum $\mathrm{L}$. & Lamiaceae & Diabetes+Hypertension & Leaves & Tea & Drink until signs disappear & 7.69 \\
\hline Lawsonia inermis $\mathrm{L}$. & Lythraceae & Diabets+Hypertension & Leaves & Infuse a hand & $\begin{array}{l}\text { Drink a cup of coffee } \\
\text { morning and night }\end{array}$ & 7.69 \\
\hline Cola cordifolia (Cav.) R. Br. & \multirow[t]{2}{*}{ Malvaceae } & Hypertension & Leaves & Decoction & Drink until signs disappear & 15.38 \\
\hline $\begin{array}{l}\text { Abelmoschus esculanthus } \\
\text { Moench. }\end{array}$ & & Hypertension & Fruit & $\begin{array}{l}\text { Decoction: in a tea } \\
\text { glass }\end{array}$ & Drink until signs disappear & 7.69 \\
\hline \multirow[t]{2}{*}{ Moringa oleifera Lam. } & \multirow[t]{2}{*}{ Moringaceae } & Hypertension & Roots & $\begin{array}{l}\text { Decoction of } 7 \text { pieces } \\
\text { of Roots cut in } 1 \text { liter of } \\
\text { water }\end{array}$ & $\begin{array}{l}\text { Drink the product obtained } \\
\text { by decoction once/day }\end{array}$ & \multirow[t]{2}{*}{46.15} \\
\hline & & Diabetes+Hypertension & Seed / Leaves & $\begin{array}{l}\text { Extract the seeds / } \\
\text { Decoction or Turn } \\
\text { leaves into powder }\end{array}$ & $\begin{array}{l}\text { Chew the seeds of pods } \\
\text { morning and evening / } \\
\text { Drink or swallow a } \\
\text { teaspoon morning and } \\
\text { evening }\end{array}$ & \\
\hline $\begin{array}{l}\text { Cymbopogon citratus (DC) } \\
\text { Stapf. }\end{array}$ & \multirow[t]{2}{*}{ Poaceae } & Diabetes+ Hypertension & Leaves & Tea & $\begin{array}{l}\text { Drink a cup in the morning } \\
\text { and a cup in the evening }\end{array}$ & 7.69 \\
\hline $\begin{array}{l}\text { Oxytenanthera abyssinica (A. } \\
\text { Rich.) Munro. }\end{array}$ & & Diabetes+Hypertension & Leaves & Decoction & Drink until signs disappear & 30.76 \\
\hline Ziziphus jujuba Mill. & Rhamnaceae & Hypertension & Leaves & Tea from 7 leaves & Drink a cup in the morning & 23.07 \\
\hline \multirow[t]{2}{*}{ Zingiber officinale Roscoe. } & \multirow[t]{2}{*}{ Zingiberaceae } & Diabetes & Rhizome & $\begin{array}{l}\text { Crush and macerate to } \\
\text { extract juice }\end{array}$ & \multirow[t]{2}{*}{ Drink until signs disappear } & \multirow[t]{2}{*}{7.69} \\
\hline & & Hypertension & Rhizome & $\begin{array}{l}\text { Powder or turn leaves } \\
\text { into powder }\end{array}$ & & \\
\hline Balanites aegyptiaca (L.) Del. & Zigophyllaceae & Hypertension & Fruit & $\begin{array}{l}\text { Remove the seed from } \\
\text { the epicarp }\end{array}$ & Suckthe epicarp & 15.38 \\
\hline
\end{tabular}




\section{Ethnobotany Research and Applications}

Table 2. List of species used in combination to treat diabetes and high blood pressure

\begin{tabular}{|c|c|c|c|c|c|c|}
\hline Species & Family & Pathologies & Plant parts used & Preparation & Consumption & $\begin{array}{l}\text { Citation } \\
\text { Frequency (\%) }\end{array}$ \\
\hline \multirow[t]{2}{*}{$\begin{array}{c}\text { Arachis hypogaea L. } \\
+ \\
\text { Tamarindus indica L. }\end{array}$} & \multirow[t]{2}{*}{ Fabaceae } & \multirow[t]{2}{*}{ Hypertension } & \multirow[t]{2}{*}{$\begin{array}{l}\text { Hull } \\
\text { Leaves }\end{array}$} & \multirow[t]{2}{*}{ Decoction } & \multirow[t]{2}{*}{$\begin{array}{l}\text { Drink in the morning and } \\
\text { evening }\end{array}$} & 15.38 \\
\hline & & & & & & 15.38 \\
\hline \multirow{2}{*}{$\begin{array}{l}\text { Terminalia avicennioides } \\
\text { Guill. \& Perr. } \\
+ \\
\text { Guiera senegalensis } \\
\text { J.F.Gmel. }\end{array}$} & \multirow[t]{2}{*}{ Combretaceae } & \multirow[t]{2}{*}{ Diabetes } & \multirow[t]{2}{*}{ Leaves } & \multirow[t]{2}{*}{ Decoction } & \multirow{2}{*}{$\begin{array}{l}\text { Drink until signs } \\
\text { disappear }\end{array}$} & 69.23 \\
\hline & & & & & & 7.69 \\
\hline \multirow{3}{*}{ 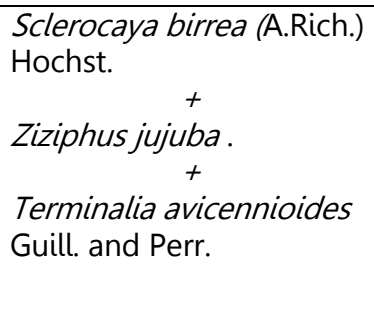 } & Anacardiaceae & \multirow[t]{3}{*}{ Diabetes } & \multirow[t]{3}{*}{ Bark or Roots } & \multirow[t]{3}{*}{$\begin{array}{l}\text { Macerate in } 1.5 \text { liters } \\
\text { of water }\end{array}$} & \multirow[t]{3}{*}{$\begin{array}{l}\text { Drink in the morning and } \\
\text { evening for } 48 \text { days. }\end{array}$} & 46.50 \\
\hline & \multirow[t]{2}{*}{$\begin{array}{l}\text { Rhamnaceae } \\
\text { Combretaceae }\end{array}$} & & & & & 23.07 \\
\hline & & & & & & 69.23 \\
\hline \multirow{3}{*}{ 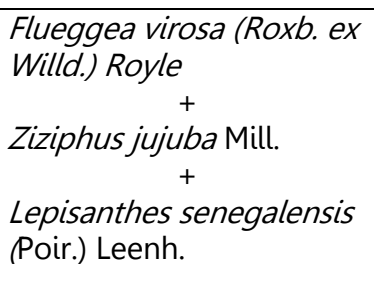 } & Euphorbiaceae & \multirow[t]{3}{*}{ Hypertension } & Roots & \multirow[t]{3}{*}{$\begin{array}{l}\text { Macerate in } 1.5 \text { liters } \\
\text { of water }\end{array}$} & \multirow[t]{3}{*}{$\begin{array}{l}\text { Drink in the morning and } \\
\text { evening for } 48 \text { days }\end{array}$} & 7.69 \\
\hline & Rhamanaceae & & \multirow[t]{2}{*}{ Leaves } & & & 23.07 \\
\hline & Sapindaceae & & & & & 7.69 \\
\hline
\end{tabular}


Deseases Diabetes $\square$ Hypertension

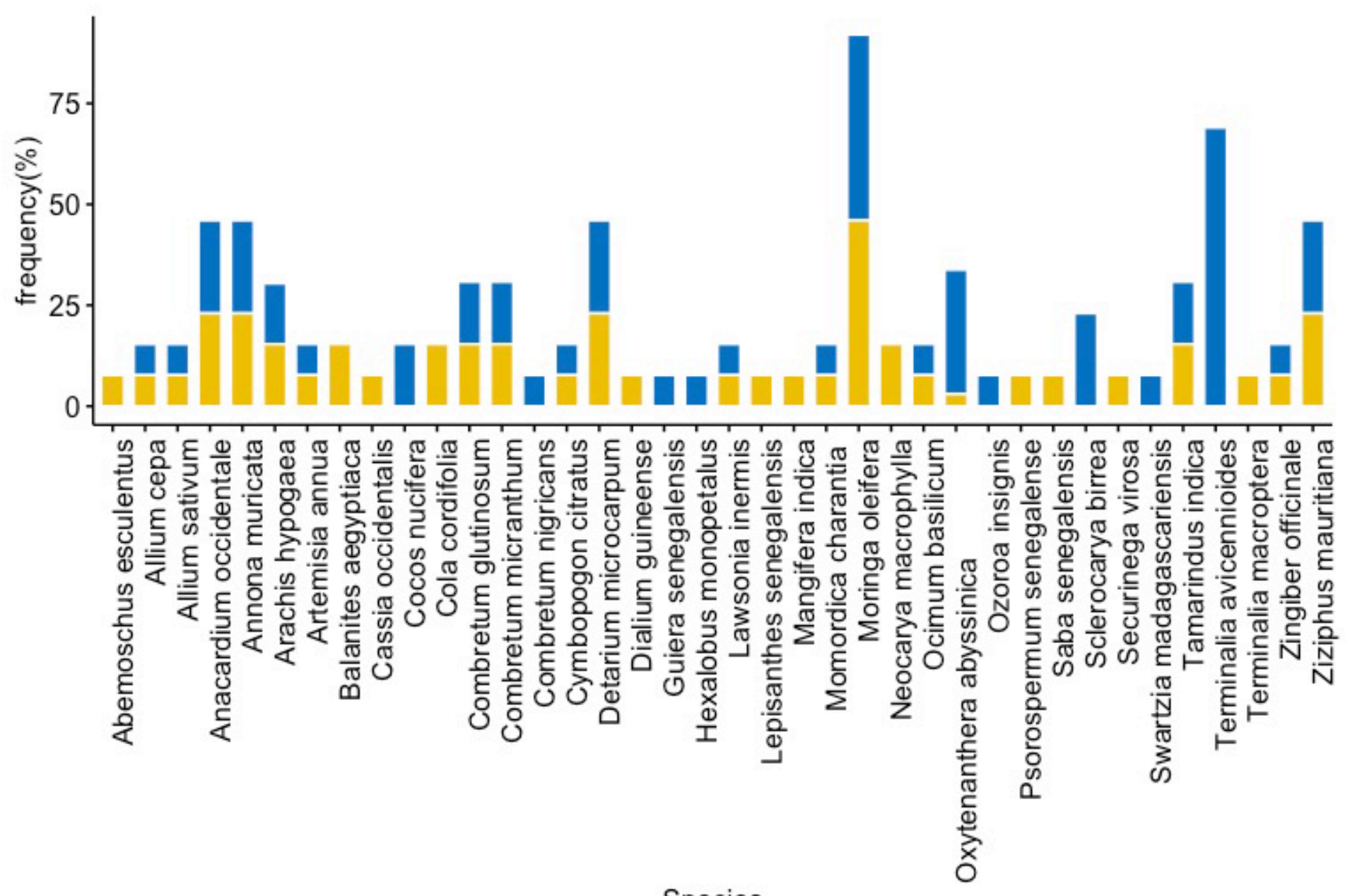

Figure 2. Species used in the treatment of diabetes and hypertension. 


\section{Plant parts used}

Leaves (56\%), bark (10\%) and roots (10\%) were the most frequently cited parts. They were mainly collected fresh in their natural environment and preserved by shade drying. One informant explained that "after harvesting, these plant parts must be dried in the shade, not in the sun to prevent the benefits from disappearing". The parts plant used varies according to the disease. Against diabetes, leaves (40\%), bark (27\%) and roots (20\%) were the most used parts. Leaves (56\%) and the shell (13\%) were used extensively to treat hypertension. For individuals presenting a combination of the association diabetes and hypertension, leaves (63\%) and fruits (19\%) constitute are the most used parts (Figure 3).

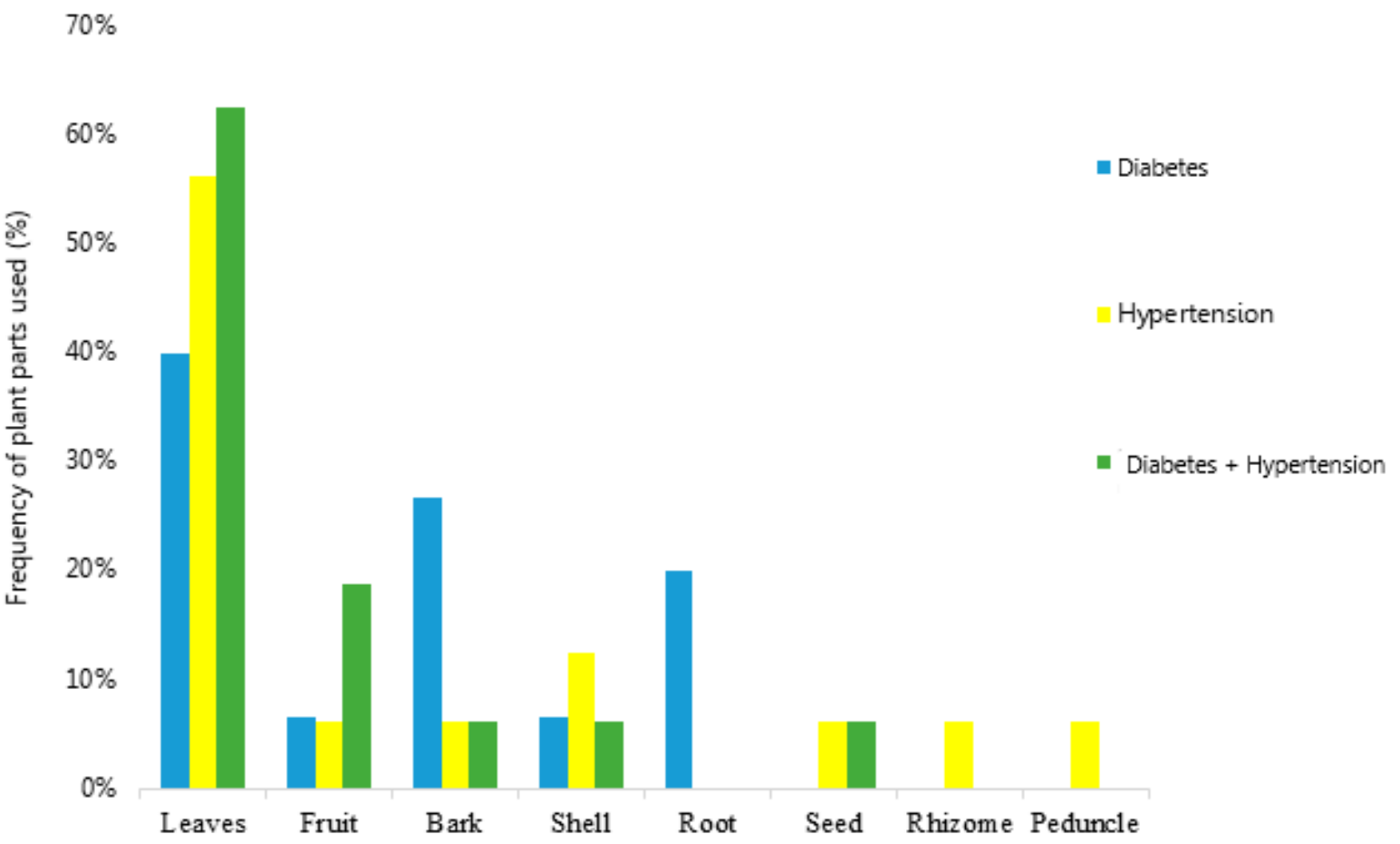

Figure 3. Plant parts for treatment of diabetes and hypertension

\section{Preparation techniques for therapeutic recipes}

When asked about how many species are used in the preparation of therapeutic recipes, the respondents indicated monospecific preparation (92\%), in which a single species (and any of its parts) constituted the bulk of the recipes. Multi-species constituted $8 \%$.

The control of the dosage is a primary concern among the respondents. The therapeutic indications given are far from uniform. It is in this sense that an interviewee explained: "lack of knowledge and lack of proper dosage, influenced by a strong desire to heal, can have harmful effects on the person suffering".

Decoction was the most common technique for preparing remedies (45\%), followed by infusion (17\%) and maceration (15\%) (Figure 4).

\section{Intake of medicine}

The administration of phyto-medicines takes place in different ways with the oral route as the main route of administration. Nevertheless, drinking is the predominant form of administration (76\%). Once prepared the remedies are either eaten (9\%), chewed (6.52\%) and sucked (4\%). Also, the administration is done by dermal route consisting of applying the preparation on the surface of the patient's head (2\%). 


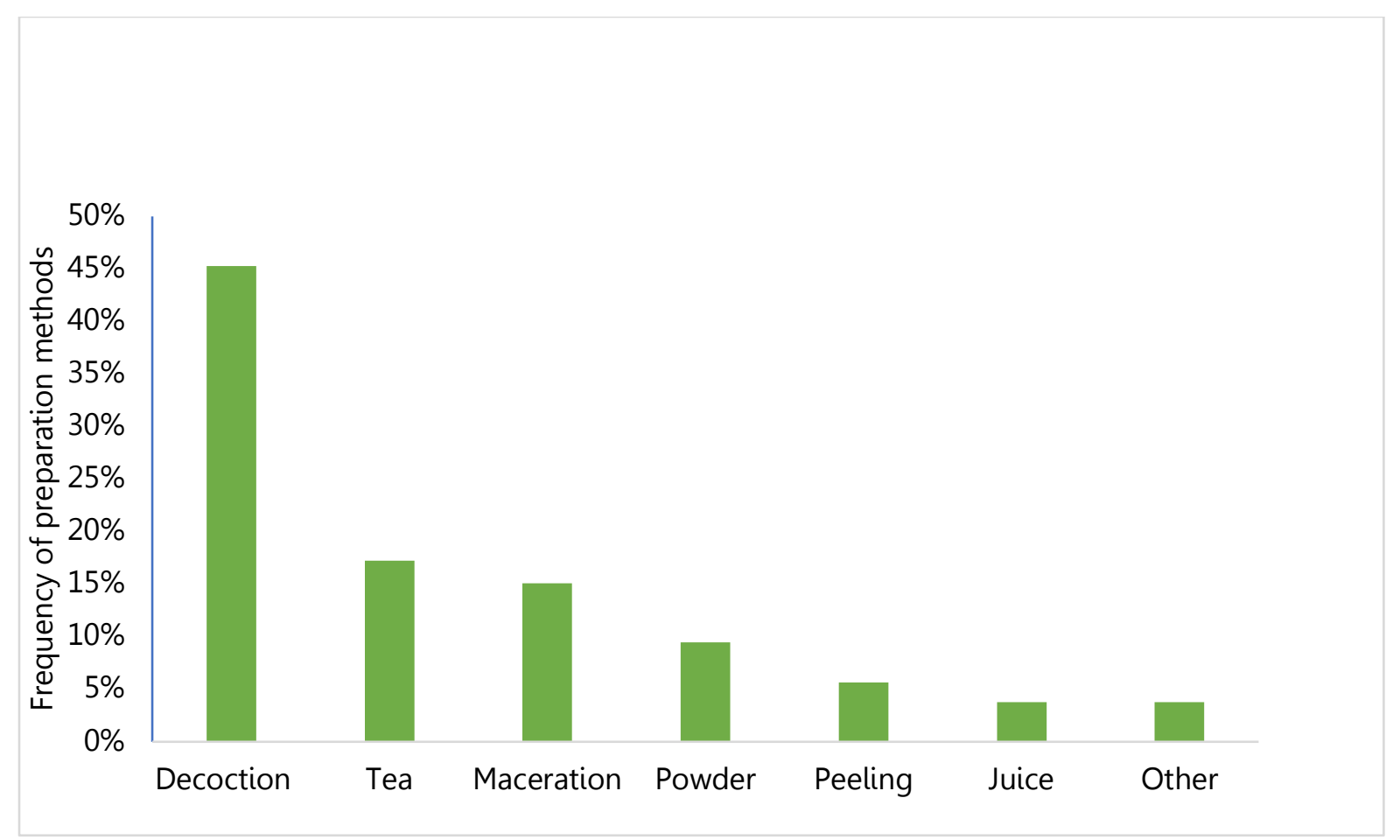

Figure 4. Methods used for preparing medicine to treat diabetes and hypertension.

\section{Discussion}

The flora used for the treatment of diabetes and hypertension is relatively diverse in the Fathala area. Thirty-eight (38) species were identified in interviews as being involved in both treatments of diabetes and hypertension. These results are different from those of Dongock et al. (2018), which identified 58 species used to treat cardiovascular diseases in southern Chad, which nevertheless testify to the existence of several clear forests in this study area; and Orch et al., (2015) in Morocco with 57 species. But the list of species identified in this study is similar to that obtained by Tra Bi et at, (2008) in Côte d'Ivoire, which revolves around 39 species.

The relatively large diversity of medicinal plants solicited for their therapeutic virtues can be explained by the extent of endogenous naturalistic knowledge as reported by Zerbo et al. (2007) and Ngene et al. (2015). The level of knowledge about plants and their therapeutic uses by local communities would result from the fact that they are mostly native to the area. As a result, these naturally maintain close relationships with the elements of the ecosystem, forged over time. This is consistent with Dongock et al. (2018) in their ethnobotanical work on medicinal plants in Chad conducted among three different ethnic groups, which assert that only the ethnic group originating in the study area has sufficient knowledge of vegetation.

The families most cited are Combretaceae, Anacardiaceae and Fabaceae. The representativeness of these main families is due to the fact that they predominate in the flora of the Fathala forest as demonstrated by Kaly (2013) through his study on the characterization of woody vegetation of the forest. Moreover, these families are the most common in the flora of Senegal, as noted in previous studies in the South and in 6 classified forests in the Sudanian and sub-Guinean zones (Gning et al. 2014, Sambou 2004) but also by Arbonnier in 2019. This availability reflects their concern for diabetes and hypertension, as do many diseases and symptoms.

Beyond this quantitative aspect, the high citation rate of these families can be explained by their richness in therapeutic virtues. Combretaceae are well known and appreciated in the field of traditional pharmacopoeia (Zerbo et al. 2007). They treat many diseases due to the secondary metabolites (saponosides, tannins, flavonoids, polyphenols) they contain, and which confer different therapeutic properties (Diouf 2002, Zerbo et al. 2011). These same substances, including flavonoids, were found in Anacardiaceae (Ouattara et al. 2016) and Fabaceae (Berrabah \& Saloua 2017).

Even though the present study recorded 18 species of plants utilized in the traditional medicine of this region of Senegal, other studies have reported between 6-22 species in the management of diabetes and hypertension (Dongock et al. 2018, Orch et al. 2015, Tra Bi et al. 2008). The common use of species in the preparation of recipes 
for the treatment of diabetes and hypertension highlights the close link between these two diseases. The onset of hypertension may precede that of diabetes and vice versa, just as the patient with diabetes requires a priori antihypertensive drugs to restore blood pressure balance (Monabeka et al. 1998, Krzesinski \& Weekers 2005). It would seem that the imbalance in blood pressure represents the greatest risk than that caused by excess blood sugar levels. According to reports from medical staff, the onset of these diseases is linked to lack of physical effort, excessive weight gains and especially to the adoption of bad eating habits (food too sweet or too salty with the use of broth, rather oily...). Moreover, this last risk factor is unanimously reported by all the local populations interviewed.

Riparian populations of the Fathala Forest have cited 11 (eleven) species as being involved in the treatment of hypertension. The species cited are among the most widely used in the Senegalese pharmacopoeia (Cisse et al. 2016, Diatta et al. 2013, Gning et al. 2014). On the other hand, the results obtained in this study differ little from those obtained from similar ethnomedicinal surveys conducted throughout Africa (Apema et al. 2011) in the Central African Republic; Orch et al. (2015) in Morocco; Dibong et al. (2015) in Cameroon). The use of some of these species in traditional disease management against hypertension has been reported in many herbal studies. In Senegal, Balanites aegyptiaca (Gning et al. 2014, Kini et al. 2008) and Dialium guineensis (Cissé et al. 2016) have been reported in the traditional management of hypertension, while in Togo, Securinega virosa, Neocaya macrophylla (Diaby et al. 2016) and Cassia occidentalis (Gbekley et al. 2018) are known to be utilized for the management of the disease. These species would be effective according to the patients surveyed who find a regular tension following the use of the remedies concocted on the basis of these. This is because Neocarya macrophylla, like Balanites aegyptiaca (Kini et al. 2008), Momordica charantia (Dongock et al. 2018) contain chemical molecules including flavonoids, tannins, alkaloids, and saponosides with antioxidant, anti-inflammatory properties, able to prevent cardiovascular risks among others, thus regulating blood pressure.

Nine species are used by people to treat diabetes, with Terminalia avicennioides being the most cited ( $F C=69,23 \%)$ and is well represented in the Fathala Forest where it sometimes forms dense stands. It is used to prevent and treat diabetes by residents. Its foaming character when prepared with tea (root or bark), according to the respondents, would be at the origin of the fact that it filters the blood well and gets rid of its impurities. This then justifies the fact that it is used daily in this area. Chemical analyses of root extracts of Terminalia avicennioides revealed significant antioxidants (Ba 2015). Chemical tests performed on Sclerocarya birrea bark extracts ( $F C=23,07 \%$ ) revealed the presence of chemical molecules including tannins, polyphenols, and saponosides that may prevent infections and hemorrhages that may occur in diabetics (Dongock et al. 2018, Mangambu et al. 2014). These same substances were found in Guiera senegalensis whose extracts of alcohol leaves tested in glucose-laden rats caused a significant decrease in blood sugar (Houacine 2012). The data show that different plant organs are used as a source of traditional remedies. Leaves are the most used part (56,25\%). The high use of the leaves could be explained by their ease of access but also by the important physiological role they play in the plant, namely photosynthesis. This makes these organs the site of synthesis of the plant's active substances (Dongock et al. 2017, Dongock et al. 2018). Tra Bi et al. (2008) believe that their ease of handling and availability throughout the year justifies that they are well sought after by users. Frequent use of bark may be due to its high chemical content, as it interacts with roots and leaves at the same time (Dongock et al. 2017). Moreover, the intense collection of 50\% of the leaves of a tree does not affect the survival of the plant (Koffi et al. 2009). As for the roots, these same authors consider that their underground location allows the preservation of the active substances from the other organs of the plant that would be thermolabile.

It appears through surveys that after the leaves, the bark $(26,67 \%)$ and the roots $(10,42 \%)$ were the main plant parts used. According to Nga et al. (2016), secondary metabolites are compounds that can be contained in some of the plant parts as well as in all organs. However, the use of vital organs represents a significant portion (20,84\%) parts of the plant removed. This then reflects a risk on medicinal biodiversity as reported by Koudouvo et al. (2017) and Assouma et al. (2018). The observation showed that even in the dry period of the year, a large proportion of woody trees continued to conserve their leaves despite the continued decline in the water parameter combined with bush fires that can be a limit of leaves perennially as well as other aerial organs such as fruits and flowers. The data obtained show that decoction $(45,28 \%)$ is the preparation technique applied to all organs of the plant used for the treatment of diabetes and hypertension with a clear predominance for the leaves. It represents a simple technique for obtaining natural remedies. This method is applied by users to recover the active substances tyat are present in the different parts of the plant and also makes it possible to reduce or even cancel the toxic effect of certain recipes (Salhi et al. 2010). Thus, even at low doses, some prepared medications are toxic and cannot be prescribed especially to fragile people such as pregnant women (Dibong et al. 2015). In addition, its application is also a huge 
saving of time and effort compared to powder processing and maceration. Of these various methods of preparing the receipts, the mono specific type dominates at $92 \%$. This predominance is justified by the relatively limited knowledge of the right dosage. This seems to work in the patient's favor in the sense that mismatched species associations are a danger (N'guessan et al. 2012). However, the discrepancy in the answers given to the question of which dosage is appropriate and sometimes for the same condition treated, shows the flaws in the field of dosage. This reflects one of the biggest obstacles facing traditional herbal medicine. Moreover, it seems to be at the origin of the reluctance felt by a large part of the population with regard to its effectiveness to date.

The therapeutic recipes developed are administered in different ways and almost exclusively orally. The drink is the most common mode $(76,12 \%)$ by which phyto-remedies are administered. This prescription of traditional medicines puts in direct contact the medicines used and the affected organs. Diabetes and hypertension affect deep-seated organs. Thus, to achieve the expected effects, any preparation must borrow the digestive tract to facilitate its assimilation ( $\mathrm{TraBi}$ et al. 2008). As a result, the methods and routes of administration of remedies depend on the organs that suffer a malfunction. This argument remains plausible since Diatta et al. (2013) argue that percutaneous administration and bathing are the most appropriate forms of treatment for dermatoses for the Bainouk people of southern Senegal.

\section{Conclusion and recommendations}

The study conducted among the residents of the Fathala Forest revealed that diabetes and hypertension are treated with various medicinal plants. Ethnobotanical surveys identified 38 plant species commonly used as sources of traditional remedies. The species identified are divided into 34 genera and 22 families. The Combretaceae, Anacardiaceae and Fabaceae are the most represented families. Therapeutic recipes are based on a single species (monospecific) and/or by combining several species (multispecific) with the leaves (56\%) as the most used parts due to their accessibility and ease of handling. Decoction $(45,28 \%)$ is the main technique used to recover the active principles of plants. The concocted remedies are mainly administered by drinking, i.e., orally, to facilitate their assimilation. This would be linked to the chronic nature of these diseases and their late diagnosis. However, these ethnobotanical survey data do not allow us to know the real therapeutic potential of these species. For that, it would be necessary to carry out phytochemical tests on some species that have not yet been studied in order to identify the molecules and to have a mastery of the right dose. In addition, for forest management and plants sustainaibility, the impact of plants medicinal use should be studied.

\section{Declarations}

Ethical approval and consent to participate: All interviewees consented

Consent to publication: Not applicable

Availability of data and materials: The data used in this work are available

Funding: This work was financially supported by USAID under the One Health work force project implemented by OHCEA.

Conflict of interest: The authors declare that there is no conflict of interest.

Authors' contributions: MD conducted the data collection in the field, carried out the data processing and analysis and produced this manuscript. FN-D supervised from the design of the research protocol to its completion, participated in the analysis of the data and commenting on the manuscript. AS participated in the development of this work and in the production of drafts. SDD assisted in the development of the research protocol, the readjustment of the article outline and the production of the final version of the article. BS and AG were involved in the conceptualization of the ideas in this manuscript and their adjustment. GEDM, APS, MBS and EAD contributed to the development of the research protocol and the collection of data in the field.

\section{Acknowledgements}

Funding was provided by USAID through the One Health workforce OHCEA project. We thank staff at the Natural Ecosystems and Environment Research Unit (NEERU) for support and people in local communities around Fathala Classified Forest for dedicated participation.

\section{Literature cited}

Apema R, Mozouloua D, Kosh-Komba E, Ngoule Y. 2011. Les plantes médicinales utilisées dans le traitement de l'hypertension artérielle par les tradipraticiens à Bangui. Geneva Foundation for Medical Education and Research 28:2011.

Arbonnier M. 2019. Arbres, arbustes et lianes des zones sèches d'Afrique de l'Ouest. Quae, Versailles, France. 
Assouma AF, Koudouvo K, Diatta W, Bassene E, Atèhèzi T, Novidzro MK, Guelly Atsu K, Dougnon J, Agbonon A, Tozo KS, Gbeassor M. 2018. Enquête Ethnobotanique Sur La Prise En Charge Traditionnelle De L'infertilité Féminine Dans La Région Sanitaire Des Savanes Au Togo. European Scientific Journal 14:358.

Ba B. 2015. Etude des effets antioxydants et anti drépanocytaires d'un extrait d'écorce de Terminalia avicennioides. PhD disseration, Cheikh Anta Diop University of Dakar, Sénégal.

Berhaut J. 1967. Flora of Senegal. Clairafrique, Dakar, Sénégal.

Berrabah C, Saloua M. 2017. Aperçu ethnobotanique et chimique des Fabacées. Master thesis, University of M'sila. Algérie.

Christenhusz MJM, Byng JW. 2016. The number of known plants species in the world and its annual increase. Phytotaxa 261:201-217.

Cisse A, Gueye M, Ka A, Ndiaye F, Koma S, Akpo LE. 2016. Ethnobotanique des plantes médicinales chez les bergers peuls de Widou Thiengoly de la commune de Téssékéré (Ferlo-Nord Sénégal). Journal of Applied Biosciences 98:9301-9308.

Diaby M, Amza T, Onivogui G, Zou XQ, Jin QZ. 2016. Physicochemical and antioxidant characteristics of gingerbread plum (Neocarya macrophylla) kernel oils. Grasas y Aceites 67:117.

Diatta CD, Gueye M, Akpo LE. 2013. Les plantes médicinales utilisées contre les dermatoses dans la pharmacopée Baïnouk de Djibonker, région de Ziguinchor (Sénégal). Journal of Applied Biosciences 70:5599-5607.

Dibong SD, Ottou MPB, Vandi D, Ndjib RC, Monkam TF. 2015. Ethnobotanique des plantes médicinales anti hémorroïdaires des marchés et villages du Centre et du Littoral Cameroun. Journal of Applied Biosciences 96:90729093.

Dimé M, Fall M. 2018. Défis et stratégies d'autonomisation foncière en contexte de changement climatique chez les jeunes du delta du Saloum (Sénégal). Revue Organisations \& territoires 27: 25-37

Diop RD, Mbaye MS, Diop I, Bassene C, Sarr O, Camara AA, Sy MTA, Noba K. 2019. Usages médicinales des plantes par la population riveraine du conservatoire botanique Michel Adanson de Mbour (Sénégal). Journal of Animal \& Plant Sciences 40:6690-6711.

Diop M. 2011. L'arbre et la forêt. Usages, préférences représentations et croyances chez les populations riveraines de la forêt classée de Patako (région de Fatick, Sénégal). PhD dissertation, Cheikh Anta Diop University of Dakar, Sénégal.

Diouf M. 2002. Inventaire des combretacees medicinales de la pharmacopee senegalaise: Enquete ethnobotanique dans la région de Dakar. PhD dissertation, Cheikh Anta Diop University of Dakar, Sénégal

Dongock DN, Bonyo AL, Mapongmestem PM, Bayegone E. 2018. Etude ethnobotanique et phytochimique des plantes médicinales utilisées dans le traitement des maladies cardiovasculaires à Moundou (Tchad). International Journal of Biological and Chemical Sciences 12:203-216.

Dongock ND, Avana TML, Djimasngar M, Goy S, Pinta JY. 2017. Importance écologique et potentialité apicole à la périphérie du Parc national de Manda en zone soudanienne du Moyen-Chari (Tchad). International Journal of Environmental Studies 74:443-57.

Doumenge C, Yuste JEG, Gartlan S, Langrand O, Ndinga A. 2001. « Conservation de la biodiversité forestière en Afrique centrale atlantique : le réseau d'aires protégées est-il adéquat ? Bois \& Forêts des Tropiques 268:5-27.

Dossou AJ, Fandohan AB, Djossa AB, Assogbadjo AE. 2021. Diversity and Knowledge of Plants Used in the Treatment of Snake Bite Envenomation in Benin. Ethnobotany Research and Applications 21: 1-20.

Gbekley HE, D Karou Si, Katawa G, Tchacondo T, Batawila K, Ameyapoh Y, Simpore J. 2018. Ethnobotanical survey of medicinal plants used in the management of hypertension in the maritime region of Togo. African Journal of Traditional, Complementary and Alternative Medicines 15:85-97.

Gobbers D, Pichard E. 2000. L'organisation du système de santé en Afrique de l'Ouest. Adsp 30:35-42.

Gning O, Sarr O, Akpo LE. 2014. Richesse de la pharmacopée malinké : rôle médicinal de l'arbre à Khossanto: (Kédougou, Sénégal oriental). Journal of Applied Biosciences 74:6043-6058. 
Gueye S. 2000. Etude sur les ressources forestières et les plantations forestières du Sénégal. Periode: 1992-1999. 61.

Houacine C. 2012. A comparative study on the anti-diabetic activity of extracts of some Algerian and Sudanese plants. Journal of Diabetes and Endocrinology 3:25-28.

Jeddi M, Ouartini ZB, Fokri-Benbrahim K. 2021. Ethnobotanical study of medicinal plants in northern Morocco (Taounate): case of Mernissa. Ethnobotany Research and Applications 21:1-23.

Kaly E. 2013. Caractérisation de la flore et de la végétation de la Forêt de Fathala (Réserve de Biosphère du delta du Saloum-Sénégal). Dissertation, Cheikh Anta Diop University of Dakar.

Kini, F, Saba A, Ouedraogo S, Tingueri B, Sanou G, Guissou IP. 2008. Potentiel nutritionnel et thérapeutique de quelques espèces fruitières 'sauvages' du Burkina Faso. Pharmacopée et Médecine Traditionnelle Africaines 15:3235 .

Koffi N, Ernest AK, Tiébré MS, Beugré K, Zirihi GN. 2009. Effect of Aqueous Extract of Chrysophyllum Cainito Leaves on the Glycaemia of Diabetic Rabbits. African Journal of Pharmacy and Pharmacology 5:501-506

Koudouvo K, Dolo A, Denou A, Sanogo R, Essien K, Agbonon A, Diallo D, Kokou K, Aklikokou K, Gbeassor M. 2017. Enquête ethnobotanique sur les plantes hepatoprotectrices utilisees par le groupe ethnique Adja du Togo, Riverain au Parc National de Togodo-Sud. Journal de la Recherche Scientifique de l'Université de Lomé 19:11-27-27.

Krzesinski JM, Weekers L. 2005. Hypertension et diabète. Revue Médicale de Liège 60:572-577.

Lykke AM. 1994. The vegetation of Delta du Saloum National Park, Senegal. AAU Reports 33 : 1-88.

Mangambu M, Mushagalusa K, Kadima N. 2014. Contribution à l'étude photochimique de quelques plantes médicinales antidiabétiques de la ville de Bukavu et ses environs (Sud-Kivu, R.D. Congo). Journal of Applied Biosciences 75:6211-6220.

Martín-López B, García-Llorente M, Palomo I, Montes C. 2011. The conservation against development paradigm in protected areas: Valuation of ecosystem services in the Doñana social-ecological system (southwestern Spain). Ecological Economics 70:1481-1491.

Mayaux P, Hugh E, Fournier A, Sawadogo L, Palumbo I, Grégoire JM. 2007. Apport des techniques spatiales pour la gestion des aires protégées en Afrique de l'Ouest. In : Fournier A, Sinsin B, Mensah G A. (éds). Quelles aires protégées pour l'Afrique de l'Ouest ? Conservation de la biodiversité et développement. Paris, France, IRD, coll. Colloques et séminaires 321-327.

Ministry of Health and Social Action. 2015. Enquête nationale sur les facteurs de risque des maladies non transmissibles STEPS 2015. Rapport préliminaire : les indicateurs-clés. Ministry of Health and Social Action, Dakar, Sénégal.

Monabeka HG, Bouenizabila E, Etitiele F. 1998. Hypertension artérielle et diabète sucré à propos de 152 diabétiques hypertendus. Médecine d'Afrique Noire 45:105-109.

Mounkaila S, Soukaradji B, Morou B, Karim S, Issoufou H B-I, Mahamane A, Ikhiri K, Saadou M. 2017. Inventaire Et Gestion Des Plantes Médicinales Dans Quatre Localités Du Niger. European Scientific Journal,13:498.

Nga EN, Pouka CK, Boumsong PCN, Dibong SD, Mpondo EM. 2016. Inventaire et caractérisation des plantes médicinales utilisées en thérapeutique dans le département de la Sanaga Maritime: Ndom, Ngambe et Pouma. Journal of Applied Biosciences 106:10333-10352-10352.

Ngene JP, Ngoule C, Pouka KCM, Mvogo OP, Dibong S, Mpondo ME. 2015. Importance dans la pharmacopée traditionnelle des plantes à flavonoïdes vendues dans les marchés de Douala est (Cameroun). Journal of Applied Biosciences 88:8194-8210.

N'guessan IAG, Kablan BJ, Kouakou NGS, Konan A, Datté AY. 2012. Propriétés bioactives de l'extrait aqueux des feuilles de Psidium guajava (Myrtaceae). Pharmacopée et Médecine Traditionnelle Africaine 16:20.

Niang-Diop F, Sambou B, Lykke AM. 2011. Contraintes de régénération naturelle de Prosopis africana: facteurs affectant la germination des graines. International Journal of Biological and Chemical Sciences 4:1693-1705. 
Orch H, Douira A, Zidane L. 2015. Étude ethnobotanique des plantes médicinales utilisées dans le traitement du diabète, et des maladies cardiaques dans la région d'Izarène (Nord du Maroc). 86:7940-7956.

Ouattara D, Kouame D, Tiebre MS, Cisse A, N'GUESSAN KE. 2016. Diversité floristique et usages des plantes dans la zone soudanienne du Nord-ouest de la Côte d'Ivoire. Journal of Animal \& Plant Sciences 31: 4815-4830.

Ouédraogo A, Thiombiano A, Hahn-Hadjali K, Guinko S. 2006. Diagnostic de l'état de dégradation des peuplements de quatre espèces ligneuses en zone soudanienne du Burkina Faso. Science et changements planétaires/Sécheresse 17:485-91.

Salhi S, Fadli M, Zidane L, Douira A. 2010. Etudes floristique et ethnobotanique des plantes médicinales de la ville de Kénitra (Maroc). Lazaroa 31:133-146.

Sambou B. 2004. Evaluation de l'état, de la dynamique et des tendances évolutives de la flore et des végétations ligneuses dans les domaines soudanien et sub guinéen au Sénégal. PhD dissertation, Cheikh Anta Diop University of Dakar.

Sofowora A. 2010. Plantes médicinales et médecine traditionnelle d'Afrique. Karthala, Paris, France.

Tendland Y. 2011. Impact de la récolte sur la survie et la croissance de deux plantes médicinales cries, Sarracenia purpurea et Rhododendron groenlandicum, dans le Nord du Québec. PhD dissertation, Montréal University.

Tra-Bi FH, Irié GM, N'Gaman KCC, Mohou CHB. 2008. Études de quelques plantes thérapeutiques utilisées dans le traitement de l'hypertension artérielle et du diabète : deux maladies émergentes en Côte d'Ivoire. Sciences $\&$ Nature 5:39-48.

Vitalini S, Iriti M, Puricelli M, Ciuchi D, Segale A, Fico G. 2013. Traditional Knowledge on Medicinal and Food Plants Used in Val San Giacomo (Sondrio, Italy) An Alpine Ethnobotanical Study. Journal of Ethnopharmacology 145: 517-529.

WHO. 2016. Rapport mondial sur le diabète. World Health Organisation, Geneva. 88p.

Zerbo P, Rasolodimey JM, Ouerdraogo ON, Van Damme P. 2007. Contribution à la connaissance des plantes médicinales utilisées dans les soins infantiles en pays San, au Burkina Faso. International Journal of Biological and Chemical Sciences 1: 262-274.

Zerbo P, Rasolodimby JM, Ouedraogo ON, Van Damme P. 2011. «Plantes médicinales et pratiques médicales au Burkina Faso: cas des Sanan ». Bois \& Forets des Tropiques 307:41-53. 